\title{
Rare Sightings of a Bryde's Whale (Balaenoptera edeni) and Sei Whales (B. borealis) (Cetacea: Balaenopteridae) Northeast of $\mathrm{O}^{\prime} \mathrm{ahu}$, Hawai' $\mathrm{i}^{1}$
}

\author{
Mari A. Smultea, ${ }^{2,3,5}$ Thomas A. Fefferson, ${ }^{3,4}$ and Ann M. Zoidis ${ }^{3}$
}

\begin{abstract}
In the Hawaiian Islands small numbers of Bryde's whales (Balaenoptera edeni) have been documented only in the Northwestern (leeward) Hawaiian Islands, and sei whales (B. borealis) have only recently been confirmed near the islands of Maui and Hawai'i. In November 2007, one Bryde's whale and two sei whale groups (including three subadults) were documented during a 7-day, systematic vessel-transect survey conducted east and northeast of $\mathrm{O}^{\prime}$ ahu. The Bryde's whale sighting is the first in nearshore $(<70 \mathrm{~km})$ waters of the main $\mathrm{Ha}-$ waiian Islands, and the two sei whale sightings are the first near O'ahu, including the first documented subadult sei whales there. The latter information suggests that Hawai'i may be a reproductive area for the endangered sei whale, whose breeding and calving ground locations remain unknown in the Pacific Ocean. Other than rare incidence, the lack of historical sightings of these two species despite many years of previous shipboard and aerial surveys off Hawai' $i$ may be due to misidentification and/or poor sea conditions prevalent in deep, offshore windward waters of the Hawaiian Islands. We recommend conducting more offshore vessel surveys for, and biopsy sampling of, these species to clarify habitat use and current stock boundaries and numbers, information important for management of Pacific populations.
\end{abstract}

Although eight species of baleen whales have been documented to occur in the Hawaiian Islands region, little is known about their distribution or occurrence, with the exception of the humpback whale (Megaptera novaeangliae) (e.g., Balcomb 1987, Mobley et al. 2000, Barlow 2006). Before 2007, the Bryde's whale (Balaenoptera edeni Anderson,

\footnotetext{
${ }^{1}$ The survey was sponsored and funded by the U.S. Navy, Pacific Fleet Environmental Office, with support from Julie Rivers and Cory Campora. Manuscript accepted 23 August 2009.

${ }^{2}$ Cetos Research Organization, Cetos Pacific, 33 Echo Ave, No. 5, Oakland, California 94611.

${ }^{3}$ Smultea Environmental Sciences, LLC, 29333 Southeast 64th Street, Issaquah, Washington 98027.

${ }^{4}$ Clymene Enterprises, 5495 Camino Playa Malaga, San Diego, California 92124.

${ }^{5}$ Corresponding author (e-mail: msmultea@msn .com).
}

Pacific Science (2010), vol. 64, no. 3:449-457

doi: $10.2984 / 64.3 .449$

(C) 2010 by University of Hawai'i Press

All rights reserved
1879) had not been documented near $(<200$ $\mathrm{km})$ the main Hawaiian Islands, and sei whale (B. borealis [Lesson, 1828]) detections were limited to recent small groups near Maui and the island of Hawai'i (e.g., Shallenberger 1981, Balcomb 1987, Mobley et al. 2000, Mobley 2004, Barlow 2006, Rankin and Barlow 2007). The taxonomy of the mediumsized baleen whale group that includes the Bryde's whale is currently confused and controversial (see Reeves et al. 2004). There are several species in that group; however, the nomenclature is not resolved, due to questions about the affinities of the type specimens of Balaenoptera edeni and Balaenoptera brydei. Therefore, the appropriate scientific name for the Bryde's whale is currently not known; however, we use $B$. edeni herein for simplicity purposes.

Differentiation of Bryde's and sei whales in the field is difficult, given their physical similarities, unless a clear view of the presence or absence of auxiliary rostral ridges is seen (see Figures 1 and 2). Until the last few decades, whalers and field observers typically did not distinguish between the two in their 


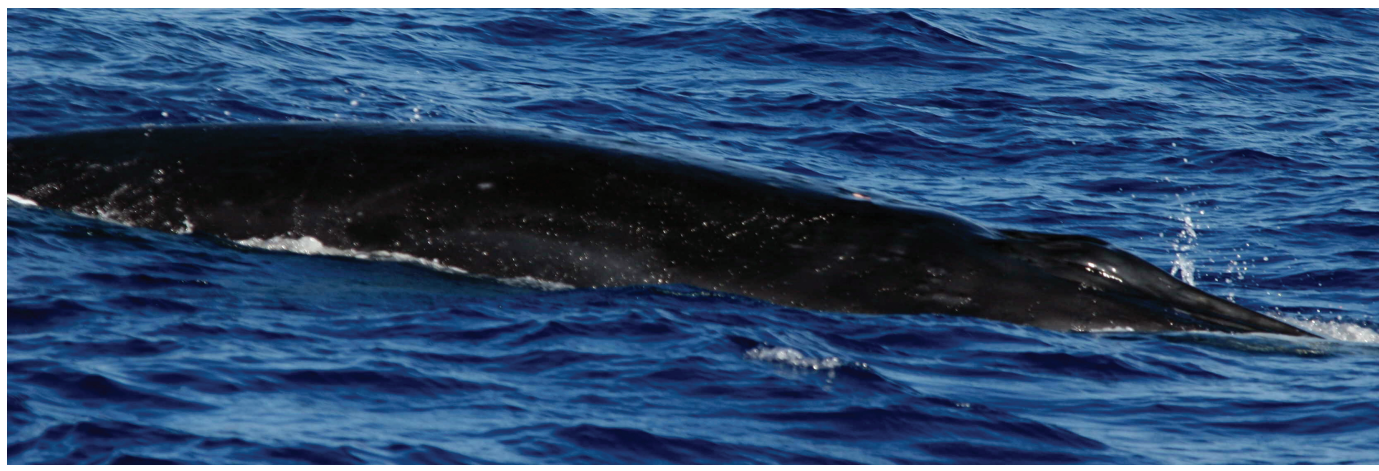

FIgURE 1. Photo of a Bryde's whale seen 13 November 2007 showing the presence of auxiliary rostral ridges, a diagnostic characteristic unique to this species (see text).

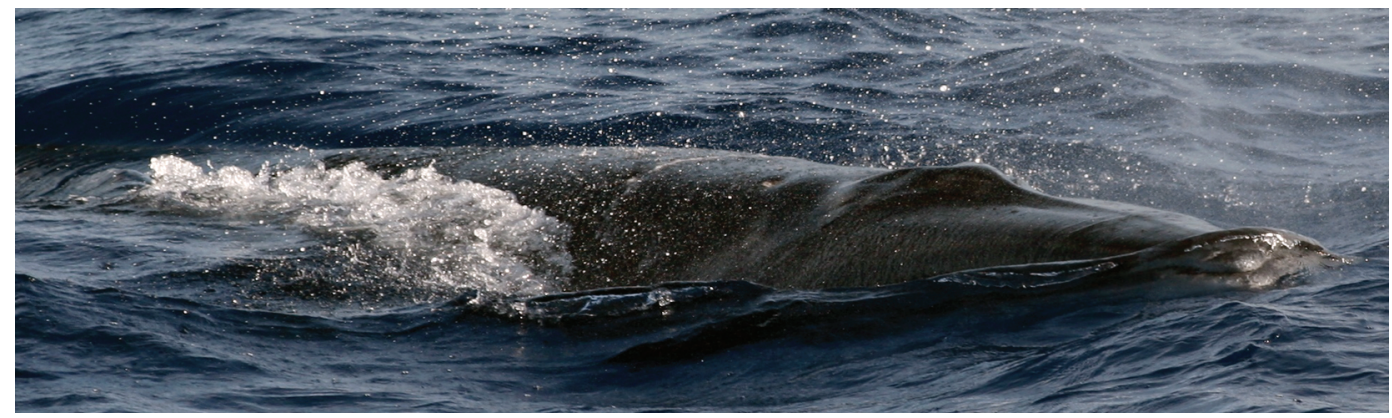

Figure 2. Photo of a subadult sei whale seen 16 November 2007 showing the lack of auxiliary rostral ridges. Several apparent cookie-cutter shark bite marks can also be seen.

records (Jefferson et al. 2008), and there is continued confusion and lack of species verification associated with many reported Bryde's and sei whale records. Furthermore, their underwater vocalizations have only recently been verified and only in a few areas (e.g., Gedamke et al. 2001, Oleson et al. 2003, Rankin and Barlow 2007). Consequently, corroborated identification data differentiating these two species are important to further understand their populations and life-history patterns, particularly for the sei whale, which is listed as Endangered under the U.S. Endangered Species Act (ESA).

The Bryde's whale is circumglobally distributed in tropical and subtropical oceans, where it is the only whale species known to habitually occur year-round (Reeves et al.
2002, Jefferson et al. 2008). It is typically one of the more ubiquitous whale species in shallow coastal waters, although it also occurs in offshore waters (Reeves et al. 2002, Jefferson et al. 2008). It tends to inhabit areas with higher primary productivity (Kato 2002). Bryde's whales do not have a well-defined breeding season, because births have been documented year-round.

Less is known about the sei whale, which is considered one of the most poorly known of all the baleen whales (see Horwood 2002). Despite being heavily hunted by whalers in both hemispheres during the twentieth century, little is known of their distribution and movements in most areas. From whaling data, sei whales are known to breed and calve during fall (Horwood 2002, Reeves et al. 


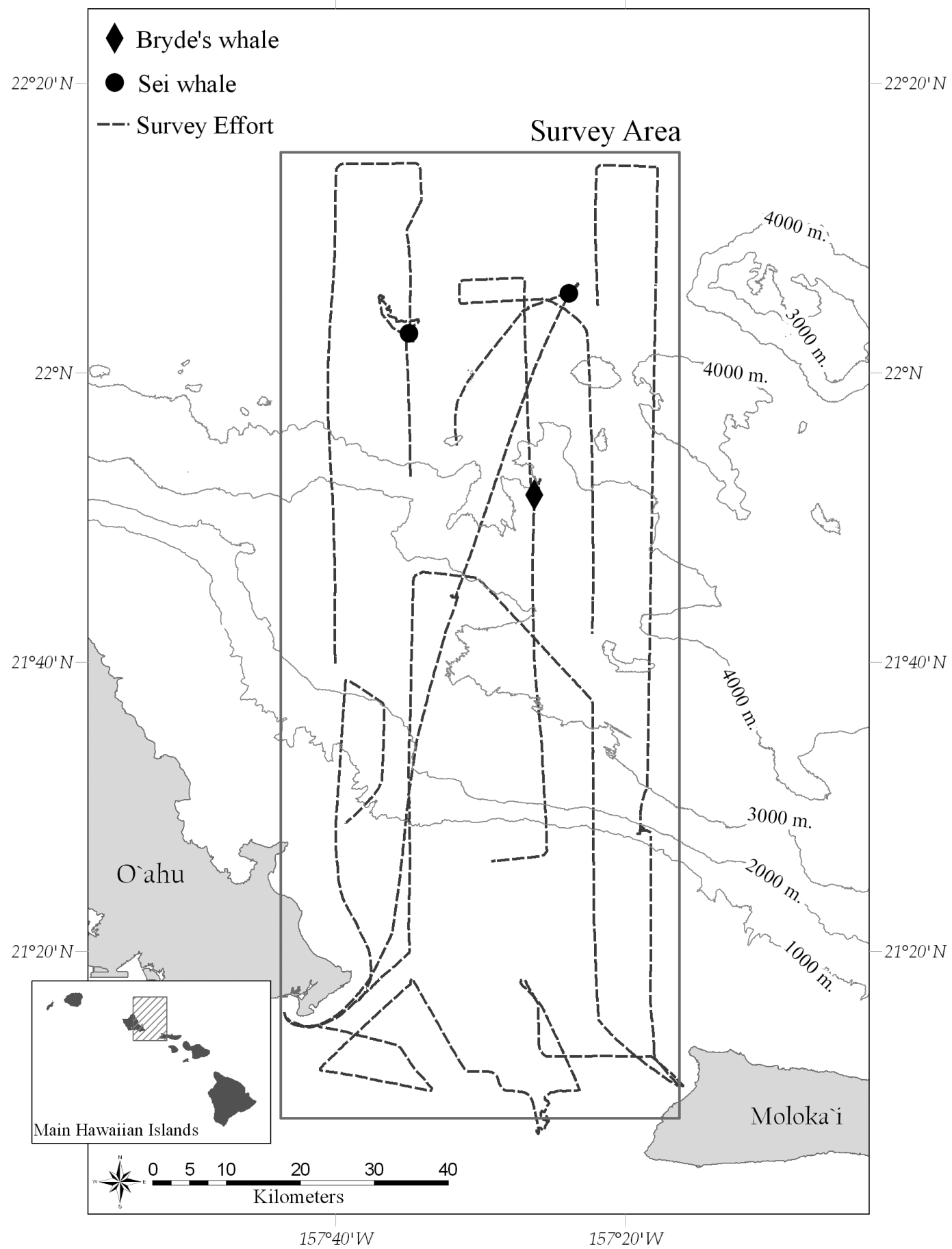

Figure 3. Map showing locations of the one Bryde's whale and two sei whale group sightings made during November 2007 northeast of O'ahu. The inset shows the location of the study area within the Hawaiian Islands. 
2002, Jefferson et al. 2008). Breeding/calving grounds of North Pacific sei whales have not been located, although 16 sei whales were recently documented in the Mariana Islands during winter 2007 (Fulling et al. 2007).

The purpose of this paper is to document the occurrence of Bryde's and sei whales, particularly subadult sei whales, near O'ahu so that they are considered in management decisions that may affect them. Further, we want to stress the importance of collecting data that allow species verification, because these species are difficult to differentiate and at a distance could be mistaken as humpback whales during their winter breeding season.

\section{MATERIALS AND METHODS}

Visual observations were conducted while following predetermined north-south linetransect survey lines in waters east and northeast of O'ahu, Hawai'i, from 11 to $18 \mathrm{No}^{-}$ vember from aboard the 29-m M/V Searcher (Figure 3). The survey grid measured approximately $55 \mathrm{~km}$ wide by $130 \mathrm{~km}$ long and encompassed waters near the coast to approximately $100 \mathrm{~km}$ from shore and over $5,000 \mathrm{~m}$ deep. Six experienced observers (four of whom each had over $15 \mathrm{yr}$ of experience) rotated through three positions. Two scanned an approximately $90^{\circ}$ arc from dead ahead (0 degrees) to just past the beam on their respective side of the vessel using $25 \times 150$ pedestal-mounted binoculars (Big Eyes Binoculars, Victoria, British Columbia, Canada) located at each forward (bow) corner of the vessel on the flying bridge platform (eye-level elevation $7.9 \mathrm{~m}$ above sea level). A third observer scanned the region nearest the vessel and out to the horizon with the unaided eye or with $7 \times 50$ reticle binoculars (West Marine, Watsonville, California). The third observer also functioned as the dedicated data recorder using a laptop computer with a real-time Global Positioning System (GPS) input. When a sighting was made, the vessel broke from the transect line to follow and conduct detailed behavioral observations of whales for up to approximately $2 \mathrm{hr}$. The vessel maintained a slow (about 2-9 km/hr) parallel course to the whales to obtain photo- graphs and/or video as possible. Field review of digital photographs taken during sightings allowed keying of species' diagnostic features.

\section{RESULTS AND DISCUSSION}

A single sei whale was seen on 12 November, followed by a single Bryde's whale on $13 \mathrm{No}$ vember and a group of three sei whales on 16 November near the same latitude as the first single sei whale sighting (Figure 3, Table 1). All three sightings occurred northeast of O'ahu in waters 2,000-5,000 $\mathrm{m}$ deep and approximately $50-70 \mathrm{~km}$ from shore. Observations continued with each group until species identification was definitively confirmed.

The Bryde's whale identification was confirmed by the presence of three rostral ridges combined with a prominent falcate dorsal fin, body length, surfacing behavior, and snout shape. The sei whales were confirmed by lack of accessory rostral ridges, slightly downturned rostrum tip, hooked ("jointed") dorsal fin, and a slight chevron on the dorsal surface (Figure 4 [see Jefferson et al. 2008]). At least 15 fresh bite scars, presumably made by cookie-cutter sharks (Isistius brasiliensis), were seen on and below the dorsal fin on the right side of the Bryde's whale, and some of the sei whales had similar (but fewer) white scars (Figures 2 and 5). The three sei whales sighted together were believed to be not more than 1-2 yr old based on their estimated body lengths of approximately $9 \mathrm{~m}$ compared with a typical reported length of about 12-16 $\mathrm{m}$ for adult sei whales (Table 1) (see Masaki 1976, Lockyer 1981, Lockyer and Martin 1983). We considered them to be subadults (defined herein as postweaned physically immature animals). Detailed behavioral observations were made during all three sightings, and animals in all three groups maintained slow travel with no apparent adverse (e.g., avoidance) reactions to the vessel. The three subadult sei whales appeared to "surf" the swells, often "gliding" approximately 1-2 $\mathrm{m}$ below the water surface parallel to the vessel with little or no movement of the tail flukes. On numerous occasions, all three sei whales approached the vessel, then crossed the bow and appeared to "ride" the 
TABLE 1

Sighting Information for the Bryde's and Two Sei Whale Sightings Made during a Vessel-Based, Line-Transect Visual Survey $11-17$ November 2007 Northeast of O'ahu, Hawai'i

\begin{tabular}{|c|c|c|c|c|c|c|c|c|}
\hline Date & Species & $\begin{array}{l}\text { Lat. (N), } \\
\text { Long. (W) }\end{array}$ & $\begin{array}{l}\text { Group } \\
\text { Size/Type }\end{array}$ & $\begin{array}{l}\text { Approx. } \\
\text { Body } \\
\text { Length (m) }\end{array}$ & $\begin{array}{l}\text { Total } \\
\text { Obs. } \\
\text { Time }\end{array}$ & $\begin{array}{l}\text { Water } \\
\text { Depth } \\
(\mathrm{m})\end{array}$ & $\begin{array}{l}\text { Beaufort } \\
\text { Sea State }\end{array}$ & Summary of Observed Behavior \\
\hline 12 Nov. & $\begin{array}{l}\text { Sei whale } \\
\quad \text { (Balaenoptera } \\
\text { borealis) }\end{array}$ & $\begin{array}{l}22^{\circ} 02.71^{\prime} \\
157^{\circ} 34.95^{\prime}\end{array}$ & 1 adult & $\sim 12$ & $145 \mathrm{~min}$ & $\sim 2,500$ & $2-3$ & $\begin{array}{l}26 \text { surfacing sequences observed. Typically made } \\
\text { two closely spaced blows followed by } 8-\text { to } 12- \\
\text { min. dives. Logging just below water surface and } \\
\text { "no-blow" rises seen. Whale seemed undisturbed } \\
\text { by vessel and paralleled and closely ( } 20 \text { to } 30 \mathrm{~m}) \\
\text { approached vessel bow repeatedly while } \\
\text { maintaining } \sim 7 \mathrm{~km} / \mathrm{hr}(3-4 \mathrm{kt}) \text { travel. }\end{array}$ \\
\hline 13 Nov. & $\begin{array}{l}\text { Bryde's whale } \\
\quad \text { (B. brydei/ } \\
\text { edeni) }\end{array}$ & $\begin{array}{l}21^{\circ} 51.90^{\prime}, \\
157^{\circ} 26.20^{\prime}\end{array}$ & 1 adult & $\sim 9$ & $50 \mathrm{~min}$ & $\sim 4,500$ & 3 & $\begin{array}{l}11 \text { surfacing sequences observed. Dives lasted 4-14 } \\
\text { min. Exhaled underwater at least three times. } \\
\text { Whale did not appear to actively avoid vessel and } \\
\text { approached on numerous occasions, maintaining } \\
\sim 6-9 \mathrm{~km} / \mathrm{hr}(3-5 \mathrm{kt}) \text { travel. }\end{array}$ \\
\hline 16 Nov. & $\begin{array}{l}\text { Sei whale ( } B . \\
\text { borealis) }\end{array}$ & $\begin{array}{l}22^{\circ} 05.70^{\prime} \\
157^{\circ} 22.59^{\prime}\end{array}$ & $\begin{array}{l}3 \text { subadult } \\
(\sim 1-2 \text { yr } \\
\text { old })\end{array}$ & $9-10$ & $64 \mathrm{~min}$ & $\sim 5,000$ & 4 & $\begin{array}{l}\text { Eight surfacing sequences observed. Dives lasted } \\
8-10 \text { min. Often traveled just below surface, } \\
\text { sometimes logged at surface. Whales repeatedly } \\
\text { followed/paralleled vessel, traveling generally } \\
\text { south at } 2-6 \mathrm{~km} / \mathrm{hr}(1-3 \mathrm{kt}) \text {. They repeatedly } \\
\text { crossed bow to within } 5 \mathrm{~m} \text {, "surfing" bow wave } \\
\text { and swells. Whale movement appeared to be } \\
\text { propelled by swells. All three whales seemed } \\
\text { undisturbed by vessel. }\end{array}$ \\
\hline
\end{tabular}




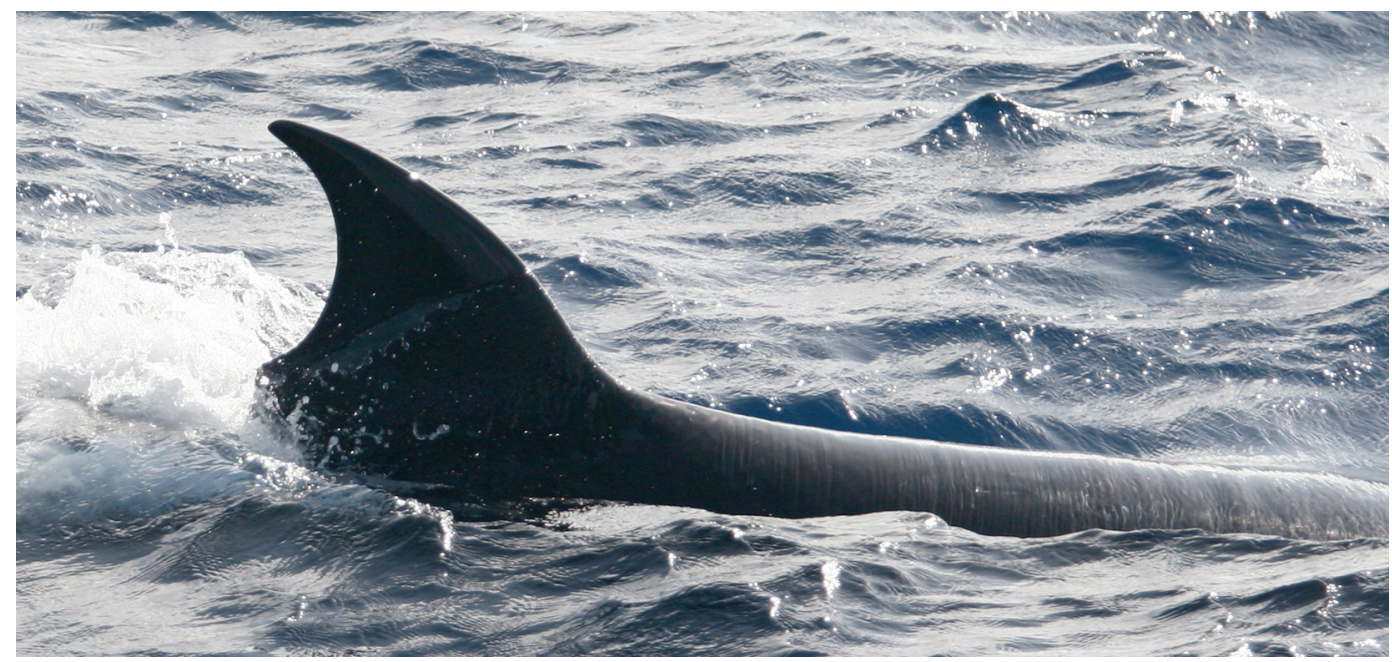

Figure 4. Photo of the dorsal fin of a sei whale seen 16 November 2007. The "jointed" shape of this dorsal fin is characteristic of the species (see text).

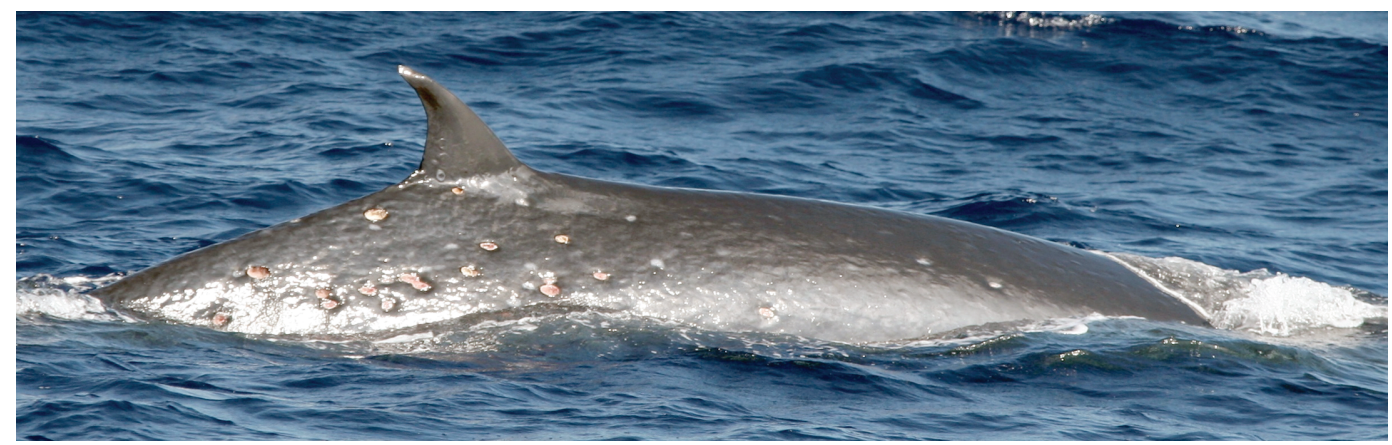

Figure 5. Photo of a Bryde's whale seen 13 November 2007 showing presumed cookie-cutter shark bite scars on its lateral body. Note the difference in dorsal fin shape between this Bryde's whale and the sei whale dorsal fin in Figure 4 (also see text for species diagnostics).

bow wave (Table 1). The surfing behavior we observed was attributed to the relatively large swells that day $(0.9-1.5 \mathrm{~m})$ and the movement of the observation vessel through the water and swells. Our observers had never seen this continuous repetitive, "leisurely" "surfing" behavior among sei whales, nor has it been reported to occur in the literature. However, sei whales appeared to "surf" swells frequently during a 4-month vessel survey in the Mariana Islands during winter 2007 (R. Rowlett, pers. comm.).
Despite several decades of vessel, aerial, and, more recently, acoustic surveys for cetaceans in Hawaiian waters, Bryde's whales have never been documented near the main Hawaiian Islands, and sei whales have rarely and only recently (2002) been documented there (Barlow 2006). Young sei whales have never been documented in this region. Since the 1970s, aerial surveys flown within about $45 \mathrm{~km}$ of the coast of the main Hawaiian Islands have never reported any Bryde's or sei whales, although fin whales have occasionally 
been seen (e.g., Herman and Antinoja 1977, Mobley et al. 1996, 2000, Mobley 2004). Many small-boat surveys have also been conducted in coastal Hawaiian waters, mostly near the "Four-Island" (Maui, Moloka'i, Lāna'i and Kaho'olawe), the island of Hawai' $i$, and Kaua'i areas (e.g., Baker and Herman 1981, Darling and McSweeney 1985, Cerchio et al. 1998, Baird et al. 2008a,b). These have mostly been restricted to waters within $18-22 \mathrm{~km}$ of the coast, with a strong bias toward leeward waters $<200 \mathrm{~m}$ deep (targeting mostly humpback whales) and to a lesser extent waters $<1,000 \mathrm{~m}$ deep for other species. Taken together, these results suggest that Bryde's and sei whales are not common in coastal waters of the main Hawaiian Islands. Other than rare incidence, the lack of historical sightings of these two species despite many years of previous aerial and shipboard surveys of Hawaiian waters (e.g., Mobley et al. 2000, Mobley 2004, Barlow 2006) may be due to misidentification and/or poor sea conditions prevalent in deep, offshore windward waters of Hawai'i.

Based on our sightings, and those of Barlow (2006), the waters just north of the main Hawaiian Islands may be part of the winter breeding range of the North Pacific sei and Bryde's whales. The estimated body lengths of the three sei whales in sighting number 3 (Table 1) would make them approximately 1 to 2 yr old; thus, they would presumably be subadults and in any event not sexually or physically mature (see Masaki 1976). The presence of young, non-reproductive whales in these waters, as well as presumably breeding adults, lends weight to the potential importance of these waters for this stock.

The responsible U.S. management authority, NOAA Fisheries, now considers that there is a Hawaiian Islands stock of sei whales estimated to number 77 individuals $(\mathrm{CV}=$ 1.06) (Barlow 2006, Carretta et al. 2007). In comparison, an estimated 493 Bryde's whales $(\mathrm{CV}=0.34)$ inhabit the entire Hawaiian Islands Exclusive Economic Zone (EEZ), primarily around the Northwestern Hawaiian Islands (Barlow 2006, Carretta et al. 2007). These Bryde's whales are provisionally managed by NOAA Fisheries as a "Hawaiian
Stock," although there is currently no biological basis for defining different stocks in the central Pacific Ocean. Given the ESA status of the sei whale, its scarcity in the Hawaiian Islands region, and its poorly known fall/ winter breeding distribution, our recent sei whale sightings in Hawaiian waters, particularly of young individuals, are of management concern (see Carretta et al. 2007). Both sei and Bryde's whales are protected by the U.S. Marine Mammal Protection Act (MMPA). Thus, though apparently rare in the main Hawaiian Islands, both species must be considered relative to potential impacts from increasing anthropogenic activities in waters of the main Hawaiian Islands, including recent interisland high-speed ferry operations, cruise ships, general vessel traffic, and military exercises.

The limited available data suggest that Bryde's and sei whales are rare near the main Hawaiian Islands, and that a small number use deep offshore waters during the fall. It is our hope that the reporting of our sightings here will lead to a better understanding of these two species in Hawaiian waters. We recommend conducting more offshore vessel surveys for, and biopsy sampling of, these species to clarify habitat use and current stock boundaries and numbers, information that is important for management of their populations in the Pacific Ocean.

\section{ACKNOWLEDGMENTS}

We thank the crew of the M/V Searcher (Captain Jon Littenberg and crew Peter Dye, Richard Littenberg, Barbara Littenberg, Noah Nugent, and Christian Werjefelt) for their hospitality and support. We also thank highly experienced observers Chris Cutler and Gary Friedrichsen. Julie Hopkins assisted as a recorder/observer and with logistics. Kaylin Quintin provided assistance during the early part of the survey. We also thank the several funders for Cetos Research NonProfit Organization because those contributions allowed for equipment purchases shared with this survey. We thank Christine Feinholz for her GIS/graphic support. Thanks to Dagmar Fertl and two anonymous reviewers 
for providing helpful comments on the manuscript.

\section{Literature Cited}

Baird, R. W., A. M. Gorgone, D. J. McSweeney, D. L. Webster, D. R. Salden, M. H. Deakos, A. D. Ligon, G. S. Schorr, J. Barlow, S. D. Mahaffy, and J. W. Durban. 2008a. False killer whales (Pseudorca crassidens) around the main Hawaiian Islands: Long-term site fidelity, inter-island movements, and association patterns. Mar. Mam. Sci. 24:591-612.

Baird, R. W., D. L. Webster, S. D. Mahaffy, D. J. McSweeney, G. S. Schorr, and A. D. Ligon. 2008b. Site fidelity and association patterns in a deep-water dolphin: Roughtoothed dolphins (Steno bredanensis) in the Hawaiian Archipelago. Mar. Mam. Sci. 24:535-553.

Baker, S. C., and L. M. Herman. 1981. Migration and local movement of humpback whales (Megaptera novaeangliae) through Hawaiian waters. Can. J. Zool. 59:460469.

Balcomb, K. C. 1987. The whales of Hawaii, including all species of marine mammals in Hawaiian and adjacent waters. Marine Mammal Fund, San Francisco.

Barlow, J. 2006. Cetacean abundance in Hawaiian waters estimated from a summer/ fall survey in 2002. Mar. Mam. Sci. 22:446-464.

Carretta, J. V., K. A. Forney, M. S. Lowry, J. Barlow, J. Baker, B. Hanson, and M. M. Muto. 2007. U.S. Pacific marine mammal stock assessments: 2007. NOAA NMFSSouthwest Fisheries Science Center Tech. Memo. 414, La Jolla, California.

Cerchio, S., C. M. Gabriele, T. F. Norris, and L. M. Herman. 1998. Movements of humpback whales between Kauai and Hawaii: Implications for population structure and abundance estimation in the Hawaiian Islands. Mar. Ecol. Prog. Ser. 175:13-22.

Darling, J. D., and D. McSweeney. 1985. Observations on the migration of North Pacific humpback whales. Can. J. Zool. 63:308-314.

Fulling, G. L., J. C. Cotton, J. A. Rivers, and
P. H. Thorson. 2007. Sei (Balaenoptera borealis) and Bryde's (B. edeni/brydei) whale co-occurrence in the Mariana Islands during the boreal winter. Page 496 in Abstracts of the 17 th biennial conference on the biology of marine mammals, December 2007, Capetown, South Africa. Society for Marine Mammalogy, Lawrence, Kansas.

Gedamke, J., D. P. Costa, and A. Dunstan. 2001. Localization and visual verification of a complex minke whale vocalization. J. Acoust. Soc. Am. 109:3038-3047.

Herman, L. M., and R. C. Antinoja. 1977. Humpback whales in the Hawaiian breeding waters: Population and pod characteristics. Sci. Rep. Whales Res. Inst. Tokyo 29:59-85.

Horwood, J. 2002. Sei whale Balaenoptera borealis. Pages 1069-1071 in W. F. Perrin, B. Würsig, and J. G. M. Thewissen, eds. Encyclopedia of marine mammals. Academic Press, San Diego.

Jefferson, T. A., M. A. Webber, and R. L. Pitman. 2008. Marine mammals of the world: A comprehensive guide to their identification. Academic Press/Elsevier, San Diego.

Kato, H. 2002. Bryde's whale Balaenoptera edeni and B. brydei. Pages 171-177 in W. F. Perrin, B. Würsig and J. G. M. Thewissen, eds. Encyclopedia of marine mammals. Academic Press, San Diego.

Lockyer, C. 1981. Growth and energy budgets of large baleen whales from the Southern Hemisphere. Pages 379-487 in Mammals in the seas. Vol. 3. General papers and large cetaceans. Food and Agricultural Organization of the United $\mathrm{Na}$ tions, Rome.

Lockyer, C., and A. R. Martin. 1983. The sei whale off western Iceland. II. Age, growth and reproduction. Rep. Int. Whaling Comm. 33:465-476.

Masaki, Y. 1976. Biological studies on the North Pacific sei whale. Bull. Far Seas Fish. Res. Lab. (Shimizu) 14:1-104.

Mobley, J. R. 2004. Results of marine mammal surveys on U.S. Navy underwater ranges in Hawaii and Bahamas. Report to Office of Naval Research, Arlington, 
Virginia. http://socrates.uhwo.hawaii.edu/ SocialSci/mobley/ONRfinal.pdf.

Mobley, J. R., Jr., M. Smultea, T. Norris, and D. Weller. 1996. Fin whale sighting north of Kaua'i, Hawai'i. Pac. Sci. 50:230-233.

Mobley, J. R., S. S. Spitz, K. A. Forney, R. Grotefendt, and P. H. Forestell. 2000. Distribution and abundance of odontocete species in Hawaiian waters: Preliminary results of 1993-98 aerial surveys. NOAA NMFS-Southwest Fisheries Science Center Admin. Rep. LJ-00-14C, La Jolla, California. http://socrates.uhwo.hawaii.edu/ SocialSci/mobley.

Oleson, E. M., J. Barlow, J. Gordon, S. Rankin, and J. A. Hildebrand. 2003. Low frequency calls of Bryde's whales. Mar. Mam. Sci. 19:407-419.

Rankin, S., and J. Barlow. 2007. Vocalizations of the sei whale Balaenoptera borealis off the Hawaiian Islands. Bioacoustics 16:137145.

Reeves, R. R., W. F. Perrin, B. L. Taylor, C. S. Baker, and S. L. Mesnick. 2004. Report of the workshop on shortcomings of cetacean taxonomy in relation to needs of conservation and management, 30 April2 May 2004, La Jolla, California. NOAA NMFS-Southwest Fisheries Science Center Tech. Memo. 363, La Jolla, California.

Reeves, R. R., B. S. Stewart, P. J. Clapham, and J. A. Powell. 2002. Guide to marine mammals of the world. Chanticleer Press, New York.

Shallenberger, E. W. 1981. The status of Hawaiian cetaceans. Marine Mammal Commission Report MMC-77/23, Washington, D.C. 
